\title{
Analysis of the Factors Affecting Tax Evasion in Greece
}

Submitted 02/11/21, 1st revision 18/12/21, 2nd revision 19/01/22, accepted 20/02/22

\section{Theodoros Kounadeas ${ }^{1}$, Nikolaos Eriotis ${ }^{2}$, Paraskevi Boufounou ${ }^{3}$, Donta Sofia $^{4}$}

\begin{abstract}
:
Purpose: This study is an attempt to capture the concept of tax evasion, to distinguish it from tax avoidance and to illustrate the magnitude of the problem in Greece.

Design/Methodology/Approach: Time series analysis and regression analysis were performed to determine which factors affect tax compliance in Greece. Data were collected from three different directorates of the Greek Independent Authority for Public Revenue (IAPR), K.E.ME.EP. (Audit Authority for Large Enterprises), K.E.F.O.ME.P. (Audit Authority for Taxpayers with Great Wealth) and Y.E.D.D.E. (Services for Investigations \& Safeguarding of Public Revenue).

Findings: The results of the research showed that the amount of fines and taxes (related to tax compliance) imposed are statistically significant and positively dependent on both the number of audits and the amounts of money imposed as fines for each audit carried out by K.E.ME.EP. and K.E.F.O.ME.P., while for Y.E.D.D.E. the identified revenue foregone depends only on the number of completed audits.

Practical Implications: Tax evasion is a phenomenon that has been of concern to the governments of all countries since ancient times, because it results in both the loss of state revenues and an unequal and unfair distribution of tax burdens. However, tackling tax evasion is a particularly difficult task, mainly because it cannot be easily detected and measured.

Originality/Value: This research points out that frequent and effective audits, combined with high fines, are a tool to reduce tax evasion and increase tax compliance.
\end{abstract}

Keywords: Tax evasion, tax avoidance, IAPR.

JEL Classification: M41, M42, M48.

Research type: Research article.

\footnotetext{
${ }^{I}$ National and Kapodistrian University of Athens, Department of Business Administration tkounadeas@gmail.com;

${ }^{2}$ The same as in 1, neriot@ba.uoa.gr;

${ }^{3}$ National and Kapodistrian University of Athens, Department of Economics, viv.boufounou@gmail.com;

${ }^{4}$ Hellenic Open University, sofiadonta@gmail.com;
} 


\section{Introduction}

Financial violations are a widespread phenomenon throughout the world. They are found in all societies, to a greater or lesser extent. Their impact on economic and social development can be very significant, depending on the extent to which they have developed. Because of these violations, the various resources available to a country are wasted or become inefficient, laws and institutions are violated or undermined, and public economy deteriorates to the detriment of public order. These violations are performed by individuals trying to hide their economic activities, either because of their illegal nature or because disclosing them would be less satisfying financially (Blackburn et al., 2012).

The key factors which affect underground activity are related to public administration and order. These include social security contributions, tax burdens, the complexity and arbitrariness of the tax system, as well as the extent of bureaucracy and the frequency of its occurrence (Blackburn et al., 2012).

Tax evasion is an intertemporal phenomenon that affects all countries. According to research by Vousinas (2017), Greece is among the countries with the highest rate of tax evasion, despite the regulations and institutions set by the European Union, and this fact creates deficits in Greece's fiscal sector. However, along with the factors that cultivate tax evasion, there are also factors that enhance tax compliance.

Empirical analysis has shown that the amount of fines and taxes (related to tax compliance) imposed are statistically significant and positively dependent on the number of audits, but also on the amounts of money imposed as fines, per audit carried out by K.E.ME.EP. and K.E.F.O.ME.P., while for Y.E.D.D.E. the identified revenue foregone depends only on the number of completed audits. The abovementioned results are confirmed by the findings of international literature, according to which frequent and effective audits, combined with the imposition of high fines, are a tool to reduce tax evasion and increase tax compliance.

\section{Literature Review}

According to Artavanis et al. (2015), the main occupational categories in which tax evasion is detected are freelancers providing services in sectors such as medicine, law, engineering, education, and media. They estimate that $43 \%-45 \%$ of freelance income goes unreported and untaxed. Their study was focused on bank lending, which is based on the debtor's personal information, occupation, employment status, reported income and debt owed. If the debtor qualifies, the funds are disbursed and the loan details (interest rate, term, installment, etc.) are established. To perform the analysis, they used data for the period from 2003 up to 2009 from eight banks on applications for consumer and credit products, as well as on mortgages approved or rejected. Their empirical approach estimates tax evasion according to the banks' decisions on the creditworthiness of the loan applicants. 
As a result, they estimate that at least $€ 26.8$ billion was not taxed in Greece during 2009. At a tax rate of $40 \%$, the foregone tax revenues represented $30 \%$ of the country's deficit.

Schneider and Buehn (2012) studied the driving forces of growth and the size of the shadow economy in thirty-nine highly developed OECD countries. The factors affecting the shadow economy are tax policies, government regulation, unemployment, freelancers and tax burden, which have different importance in these thirty-nine countries. This study provides a different analysis on the extent to which a particular factor contributes to the size and growth of the shadow economy and how the relative impact varies from country to country. At the same time, it provides answers to questions such as whether direct taxation is more important than indirect taxation and to what extent does direct taxation help to improve the labour market.

Governments thus, do possess a tool to combat the shadow economy. The size of the shadow economy can be measured, either at a microeconomic level using surveys or questionnaires, or at a macroeconomic level. The use of macroeconomic methods such as the Multiple Indicators Multiple Causes approach (MIMIC) shows that shadow economy is the result of several causes such as the tax rate, the level of unemployment and the degree of regulation. The estimation results show that the causal variables, which are personal income tax, indirect taxes, unemployment, freelancers, GDP growth and business freedom, are statistically highly significant variables.

Alm and Torgler (2004) studied tax compliance across different countries. In their research, they make an attempt to investigate the differences in tax ethics between countries, i.e., tax consciousness, which varies from country to country. The survey is based on representative national samples of at least one thousand (1000) individuals in each country, in more than forty (40) countries in total. All surveys were conducted through face-to-face interviews in the homes of the interviewees and in their respective national languages.

According to the World Values Survey (WVS), which studies the behaviour of people from different sectors in the US and Spain, the results show that tax consciousness in the US was higher than in Spain. The study is then extended by considering the US and fourteen (14) European countries. The conclusion was the same, that tax consciousness is higher in the USA. The Global Values Survey sets tax awareness as the dependent variable.

Mara (2015) identified the determinants of tax havens in the real economic context. Tax havens are countries that offer low or zero taxation. In addition, they ensure high levels of secrecy and have a strong network of financial services that allows those who want to avoid taxation to implement sophisticated strategies to achieve their goal. These include a combination of favourable conditions in order to create 
the financial and tax policies necessary for the development of tax evasion and avoidance, using tools and mechanisms such as offshore companies.

The development of tax havens has been favoured by particular factors at a macroeconomic level, but also by the non-tax compliance behaviour of individuals seeking different ways of avoiding taxation. It used an econometric model based on World Bank data and other databases located in all countries. To control determinants, Mara used a panel data regression in a probit model. The study concluded that for a country to be considered a tax haven, not only does the level of tax rates have to be low, but also the share of services in GDP. Countries with a relatively small population and high GDP per capita can become tax havens (Mara, 2015).

Crocker and Slemrod (2004) studied corporate tax evasion in the context of the contractual or employment relationship between a company's shareholders and the CFO who has private information about the extent of legally permissible deductions on taxable income and who may engage in illegal tax evasion. Using a framework for measuring tax misrepresentation, they characterize the optimal incentive compensation contract for the operator of the firm's tax affairs and, in particular, how the form of this contract changes relative to alternative policies imposed by tax authorities. This optimal contract can be adapted to compensate for the effect of sanctions against illegal tax evasion. The result of the study is interesting because it is not directly related to the policies implemented, sanctions imposed directly on the $\mathrm{CFO}$ are more effective in reducing tax evasion than those imposed on shareholders.

Albulescu et al. (2016) studied the long-term relationship between entrepreneurial activity and tax evasion in fifteen European countries. They found out that tax evasion and corruption negatively affect entrepreneurship. They used a regression analysis with panel data and realised that there is a long-term relationship between the variables and that tax evasion and corruption negatively affect overall entrepreneurship. They also show that the impact of tax evasion is smaller in cases of individuals who started an entrepreneurial activity not because they conceived it as an opportunity but because they had no better job options (necessity-driven entrepreneurs). This derives from the fact that these entrepreneurs were forced to start a business activity without other sources of income, and they are, thus, less affected by the institutional failure of the state to tackle tax evasion in order to promote entrepreneurship.

Goerke (2016) investigated tax evasion related to operating profits as well as the ways it can affect the prediction of low boundaries for entry into a market, using the Cournot-Nash oligopoly. Tax evasion increases the number of businesses in the market equilibrium and can change the number that maximizes their welfare. The study considers a market for a homogeneous good in which companies maximize profits through quantity competition, taking other firms' output as given choices (Cournot-Nash behavior). The investigation concluded that tax evasion on operating 
profits affects the number of firms in the industry. If tax evasion increases profits, entry becomes more attractive and hence not paying taxes encourages entry.

Therefore, the number of welfare-maximizing firms changes. The direction of change depends, among other things, on the relationship between tax base and tax evasion behaviour.

Gokalp et al. (2017) studied why companies avoid taxation. They studied companies operating in countries with different institutional backgrounds, comparing the incentives and constraints of staying in the formal sector with the competitive pressures from the informal sector. The data for their regression analysis came from the World Bank and from a questionnaire they conducted about the investment climate. The survey was conducted in one hundred and seven countries (107) between 2002 and 2006. They argued that a combination of factors explains, to a great extent, the tax avoidance decisions of companies. The findings highlight the dark side of competition, particularly when it comes from unfair sources. They also shed light on how this impact is moderated by the institutional conditions in the environment.

The research conducted by Mylonas et al. (2010) attempts to estimate tax evasion by comparing information from national accounts with those reported to tax authorities in order to detect discrepancies. As the availability of data from tax authorities is limited due to confidentiality issues, they also examined the distinct differences in returns from income taxation.

The determination of the unreported or partially reported part of household income is achieved through three complementary methods. The first method is based on a comparison of the effective tax rates with those of the euro area, using national accounts data to estimate the tax base and then using legal tax rates to calculate effective rates. The second method uses the difference between national household income accounts and the corresponding reported income information obtained from the TAXIS system to estimate income. The third method uses the properties of the two-way distribution of reported incomes for the two major categories of taxpayers, wage earners and self-employed persons. The compensation of the two income categories derives from these properties combined with national accounts data. In this way, the size of the tax base is estimated. This study found that the unreported income of individuals is estimated to constitute $20 \%$ of the Greek annual GDP, i.e., 50 billion euros (Mylonas et al., 2010).

Kleven et al. (2009) studied a simple agency model to explain why the declaration of employee's income by their employers reduces tax evasion, even if there are no frequent audits and considerable fines. Some companies have a large number of employees and perform various complex record-keeping procedures, which require the use of large business archives. If the record keeping is not done properly, any employee can report collusive tax fraud between employees and employer by 
disclosing the actual archives to tax authorities. The study shows that if a business is large enough, such whistleblower threats will make income reporting successful, even with low penalties and without frequent audits. They incorporated this model into the standard Allingham-Sandmo model of tax evasion, and into a macroeconomic growth model as well, according to which, the size and complexity of the firm grows with technological progress.

Vousinas (2017) examined two serious problems, tax evasion in Greece and the shadow economy. He studied the determinants that led to the growth of the shadow economy. Borrowing leads to an increase in public debt, while external borrowing leads to an increase in interest rates in order to raise capital from abroad, which results in the decrease of currency circulation in the market and a decrease in the private investment which is necessary for growth. The conclusions of the study are that tax evasion has created deficits in the Greek economy, which cannot be covered effectively, forcing the government to borrow both internally and externally. The overall conclusion of the study is that tax evasion has led to Greece's economic stagnation and loss of competitiveness.

Remeikiene et al. (2014) studied the determinants of the shadow economy, especially in Greece, in the period from 2008 to 2013. In 2008, the average share of the shadow economy was $19.4 \%$ in Europe and $24.3 \%$ in Greece, while in 2012 the average share of the shadow economy was $19 \%$ in Europe and $22.3 \%$ in Greece. Comparing 2009 with 2008 shows that the share of the shadow economy in GDP increased by $0.5 \%$ across Europe. The study involved multiple/simple regression and correlation analysis in the years from 2008 to 2013. Only factors with a correlation coefficient equal to, or greater than, 0.60 were selected.

The size of the underground economy reflects individuals' motivations to hide their activities. In economic recession there is an increase in the number of unemployed and a decrease in income. This creates fears, uncertainty about the future and ultimately a shift to the shadow economy. The results of the research showed that macroeconomic factors influence the level of the shadow economy, while the most important factor turned out to be the tax rate (Remeikiene et al., 2014).

Schneider et al. (2010) reported that shadow economic activities are part of the real life of people around the world. Most societies try to limit them through measures such as persecution, punishment, education, and economic development. The most effective and efficient allocation of resources is vital for a country to be able to gather information on the size and extent of the shadow economy, as well as on the underground activities and the frequency at which they occur. Schneider et al. (2010) investigated the shadow economies of one hundred and sixty-two countries (162), including developing countries, Eastern European countries and high-income Central Asian countries, over the period from 1999 to 2007, i.e., countries at various stages of economic development, and provided some information on the main causes of the shadow economy. 
They used the method of Multiple Indicators Multiple Causes approach (MIMIC) and concluded that there is a clear negative trend in the size of the shadow economy. The factors positively associated with the shadow economy were increased tax burden combined with market regulations, quality of public goods and technology. Three main conclusions were drawn:

> The countries where the shadow economy showed increasing trends those where underground activities reached an extremely high size as a percentage of GDP (up to 33\%). However, the negative relationship of the shadow economy over time was clear.

$>$ Shadow economies are a complex phenomenon that occurs in all types of economies.

$>$ There are regional imbalances in the level of the shadow economy. The highest imbalances were observed in African countries and the lowest were found in OECD countries.

Williams and Renooy (2013) studied how undeclared work has been tackled in the twenty-seven EU member states and Norway, since the beginning of the 2008 recession. There are two opposing views on the size of undeclared work in times of economic crisis. One view is that undeclared work increases relative to declared work. The opposite view is that undeclared work decreases due to low demand in times of economic recession and a lack of liquidity.

Another issue examined in this paper is how undeclared work has changed in terms of its size since the start of the recession. There was also the issue about who is affected by the reduction in undeclared work during the economic crisis. In Nordic countries, the answer to this question was that those who declared their work had increased their earnings. The use of undeclared work had a greater negative effect in the Nordic countries than the effects of the reduction in undeclared work in other countries during the economic crisis.

The researchers used the Multiple Indicators Multiple Causes approach (MIMIC) Method. The conclusion from the research is that a wide spectrum of approaches and measures have been adopted across the EU. Although non-compliance remained the prevailing approach in most member states, there has been a wider adoption, allowing for measures that provide encouragement and incentives for both employees and employers (Williams and Renooy, 2013).

Williams and Horodnic (2015), suggested that the proliferation of illegal wage practices in Southern European societies results from the lack of alignment between institutional rules and the unwritten rules that exist in society and which reflect the beliefs of citizens. The survey was conducted in 2013 and examined whether employers in five Southern European countries fraudulently avoid tax and social insurance payments by paying employees a portion of the wages they declare in their accounts. 
There is a considerable correlation between the extent of wage reporting and the degree of institutional asymmetry in these societies, leading to widening effects. Then the effects of illegal wage practices are, in turn, widened. The survey was conducted in collaboration with Eurobarometer (No. 402) and included 1626 face-toface interviews conducted with employees in Cyprus, Greece, Spain, Portugal, Malta, Spain, and Italy. One in thirty-three employees reported that, in the last twelve months, they received 50\% of their gross salary as additional, undeclared wages. Such payroll practices seem to be more common in Southern Europe than in the North and also more common in Eastern than in Western countries.

Vlachos et al. (2015) described the determinants of shadow economic activities and corruption in Greece, as reported by relevant surveys. In addition, they explored the concepts of tax evasion and undeclared work. Their principal objective was to collect primary data indicating the profile of the Greek taxpayer through a questionnaire and to determine the orientation of the econometric analysis. The study aims at a complex approach to the assessment of the shadow economy and corruption in Greece. The major advantage of direct (microeconomic) measurement over indirect (macroeconomic) approaches is the ability to immediately define the incentives in favor of participating in shadow economic activities and to reveal the supply, demand, and remuneration of undeclared work, in addition to reflecting more accurately on tax evasion in the industry and different income groups.

More specifically, Vlachos et al. (2015) developed a questionnaire that included the size and definition of tax evasion in Greece, the size and definition of corruption and the size of undeclared work. At the end of the questionnaire, questions are asked about the frequency of shadow economic activities in the country. The questionnaire was answered by more than two thousand (2000) individuals and entrepreneurs. The conclusion that was drawn based on the MIMIC method is that tax burden, social security, free employment, unemployment, and tax regulations are the main factors that cause the development of the shadow economy in Greece. The interaction between the shadow economy and the normal economy in the business world and vice versa was also investigated.

Based on the MIMIC method, they concluded that the Greek shadow economy was estimated to be between 26 and $28 \%$ of GDP, considering that the financial system in Greece during the period of 1984 to 1997 as a percentage of GDP was between 19 and $37 \%$. In this study, the concepts of tax evasion and undeclared work were also investigated. In the case of tax evasion, the literature shows that the self-employed tend to evade taxes, while employees comply with government obligations.

According to Eurobarometer (No 402), in the second quarter of 2013, 30\% of employers in Greece employed people in an undeclared work regime. This conclusion matches the result of the MIMIC method, which showed that the size of undeclared work ranges from $1 / 4$ to $1 / 3$ the sizes of the shadow economy. The high proportion of undeclared work in Greece is not only the result of employees and 
pensioners seeking extra work, but also of the unemployed doing this (Vlachos et al., 2015).

Vlachos et al. (2015) proposed an econometric method and questionnaire structure at the end of the survey to show the frequency of shadow economic activities and corruption in Greece and to reflect the profile of the Greek tax evader. The primary data were examined through logit or probit analysis, based on the predictors of the frequency of shadow economic activities and the corresponding trend score.

Kaplanoglou and Rapanos (2011) reported that the large shortages in state revenues are at least partly due to the poor performance of the tax administration mechanisms that exist in Greece and the high tax evasion (Mylonas et al., 2010). They conducted a survey on the path leading to fiscal debt, based on secondary research for the period from 1999 to 2009, by analyzing the State Budget Introductory Reports, and demonstrate the Greek fiscal governance for the period up to the fiscal crisis, as well as the fiscal outcomes.

The numerous tax reforms introduced each year were mainly related to changes in tax bases and tax rates, while the structural weaknesses of the tax administration systems remained intact. The fiscal crisis in Greece in 2010 sparked renewed interest in reducing tax evasion and was seen as a way to increase tax revenues and to achieve a more equitable distribution of the public burdens (Kaplanoglou and Rapanos, 2011).

Kaplanoglou and Rapanos (2011), considering both their international experience and the characteristics of the Greek reality, reported an approach that aimed to improve tax administration in Greece. They found out that the accumulation of fiscal deficits seems to have been a choice made by Greek governments. At the same time, there were no internal or external mechanisms that could effectively identify systematic deviations of public revenues and expenditures from the goals set. As a consequence, there was no initiative to reduce them. But things, according to their research, were not that disheartening. Greece, when the fiscal crisis began, seemed to be in the early stages of fiscal reform which would bring significant benefits. With this reform, the gains would not only refer to the numerical reduction in the budget deficit, but also to the fair distribution of the tax burden as a result of the fight against tax evasion.

\section{Empirical Research}

Tax evasion is a major blow to a country's economy, especially a country in recession and with low competitiveness, such as Greece. Reducing tax evasion and preventing the erosion of the tax base is one of the most important economic policy objectives of the Greek government. To this end, the Independent Authority for Public Revenue (IAPR) aims to enhance tax compliance and protect society as a 
whole. In order to achieve the above-mentioned goals, regular and extraordinary audits are carried out both on legal and private entities.

The purpose of this study will be to investigate the level at which the target set by the government and the IAPR is achieved, by making use of appropriate indicators of audits, fines imposed and recoverability. The study will also examine the evolution of the efficiency of the tax administration and identify specific trends in the evolution of confirmed revenues derived from audits carried out by tax authorities, as well as their correlation with the number of audits carried out during the same period.

The aim is to ascertain whether the stricter legislation and the increase in the number of audits have affected taxpayers' compliance. The increase in tax compliance and the tightening of the tax institutional framework will also result in a reduction of tax evasion and shadow economy in Greece.

For the empirical part of this study, data on the audits carried out by the tax audit mechanisms and the amounts of taxes and fines assessed from these audits were obtained from the website of the Independent Authority for Public Revenue (IAPR), concerning the monitoring of the performance of the Tax Administration through the review of Critical Indicators (IAPR, 2019). The sample on which the analysis will be based consists of monthly data covering the period from January 2013 to December 2020. The data extracted are quantitative and continuous, in billions of euros. In addition, the time-signature variable has been coded so that the relevant checks for averages and variances can be carried out.

In the empirical part, a descriptive analysis and presentation of the evolution of these variables over time was attempted, at least for the years where data are available from the IAPR. Correlation and regression analysis were then carried out, with the creation of three different models, one for each audit service (K.E.ME.EP., K.E.F.O.ME.P. and Y.E.D.D.E.). The dependent variable used was revenue established for the first two services and revenue foregone in the case of Y.E.D.D.E. The independent variables used were the numbers of controls carried out and the number of staff allocated to these controls by each service.

\section{Data Analysis}

The objective of this empirical analysis is to highlight the correlation between the variables and the factors that influence the final amount of money that is imposed on tax offenders as fines. Accordingly, multiple regression models were created, with the dependent variable being the taxes and fines assessed in the case of K.E.ME.EP. and K.E.F.O.ME.P. and the foregone profits identified during the audits in the case of Y.E.D.D.E. First, a check is carried out to establish whether the conditions for the regression model to be statistically significant are met, followed by the calculations of the regression equations (Figure 1). 
Figure 1. Regression residuals plot-K.E.ME.EP.

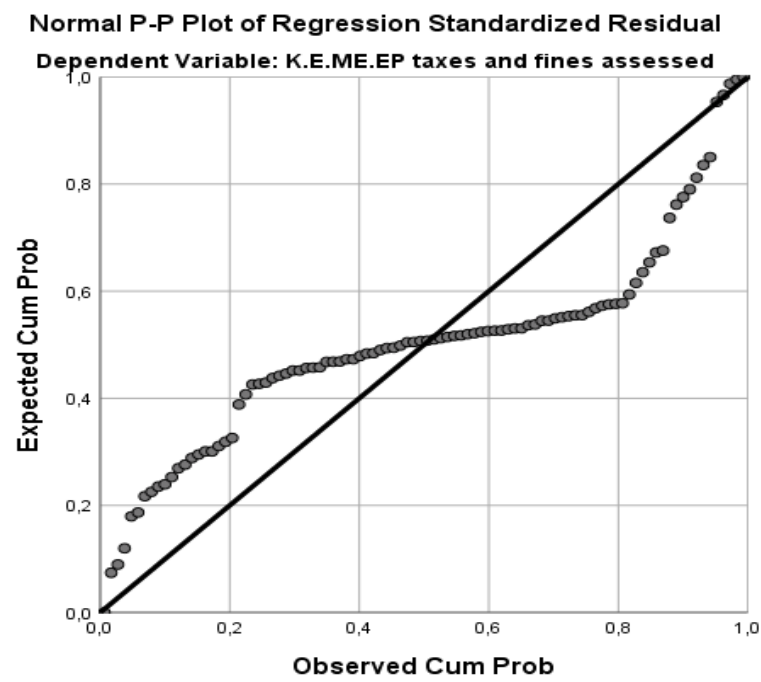

Source: Own study.

From this graph, we can see that there are significant deviations from normality for our data, as the residuals show significant deviations from the diagonal. However, since our sample is quite large, the assumption of normality is not that significant and therefore this is not a particularly big problem (Field, 2009).

Table 1. Multilinearity tests - K.E.ME.EP.

\begin{tabular}{|l|c|c|}
\hline & Tolerance & VIF \\
\hline Number of completed K.E.ME.EP. audits &, 977 & 1,024 \\
\hline Amounts of money assessed per K.E.ME.EP. audit &, 981 & 1,019 \\
\hline K.E.ME.EP. staff &, 989 & 1,011 \\
\hline
\end{tabular}

Source: Own study.

The next condition is that of no multilinearity. To test the hypothesis, we calculate the statistics shown in Table 1. The tolerance values are not close to zero, and none of the VIF values are greater than 10 . Thus, there is no multilinearity problem in our data (Field, 2009).

Table 2. Descriptive regression statistics - K.E.ME.EP.

\begin{tabular}{|c|c|c|c|c|c|}
\hline Model & R & R Square & $\begin{array}{c}\text { Adjusted } \\
\text { R Square }\end{array}$ & $\begin{array}{c}\text { Std. Error of the } \\
\text { Estimate }\end{array}$ & Durbin-Watson \\
\hline 1 &, $893^{\mathrm{a}}$ &, 798 &, 792 & 44,79547 & 1,751 \\
\hline
\end{tabular}

a. Predictors: (Constant), K.E.ME.EP. staff, Amounts of money certified per K.E.ME.EP. audit, Number of completed K.E.ME.EP. audits

b. Dependent Variable: K.E.ME.EP. taxes and fines assessed

Source: Own study. 
The test for the absence of autocorrelation must be carried out using the DurbinWatson statistic. The value of the statistic must be between the values of 1.7 and 2.3 so, an autocorrelation problem does not occur (Field, 2009). In our case, the value of the statistic is 1.751 and therefore it does not seem to be a problem. We can proceed to calculate the regression equation.

The value of the coefficient of determination is equal to 0.798 , which means that $79.8 \%$ of the variability of the taxes and fines collected by the K.E.ME.EP. is explained by the variables in the model. The value is quite high, but we need to ascertain which of the variables are statistically significant. For this reason, we created the following Table 3 in SPSS.

Table 3. Regression equation coefficients - K.E.ME.EP.

\begin{tabular}{|l|c|c|c|c|c|}
\hline \multirow{2}{*}{ Model } & \multicolumn{2}{|c|}{ Unstd. Coeff. } & Std. Coeff. & \multirow{2}{*}{ t } & \multirow{2}{*}{ Sig. } \\
\cline { 2 - 7 } & $\mathbf{B}$ & Std. Err. & Beta & &, 352 \\
\hline (Constant) & $-73,872$ & 77,339 & &,- 955 &, 342 \\
\hline Number of completed K.E.ME.EP. audits &, 701 &, 123 &, 271 & 5,710 &, 000 \\
\hline $\begin{array}{l}\text { Amounts of money assessed per K.E.ME.E } \\
\text { audit }\end{array}$ & 29,036 & 1,547 &, 888 & 18,774 &, 000 \\
\hline K.E.ME.EP. staff &, 291 &, 420 &, 033 &, 692 &, 490 \\
\hline
\end{tabular}

Source: Own study.

For a regression coefficient to be statistically significant at the 5\% level, its significance value (Sig.) should be less than this threshold (Field, 2009). As we can see in Table 3, this condition applies to the number of completed audits of K.E.ME.EP. and the confirmed amounts of money per audit, but not to the total staff of the agency. As a consequence, only the first two variables are statistically significant and should be considered when calculating the model.

Figure 2. Regression residuals diagram - K.E.F.O.ME.P.

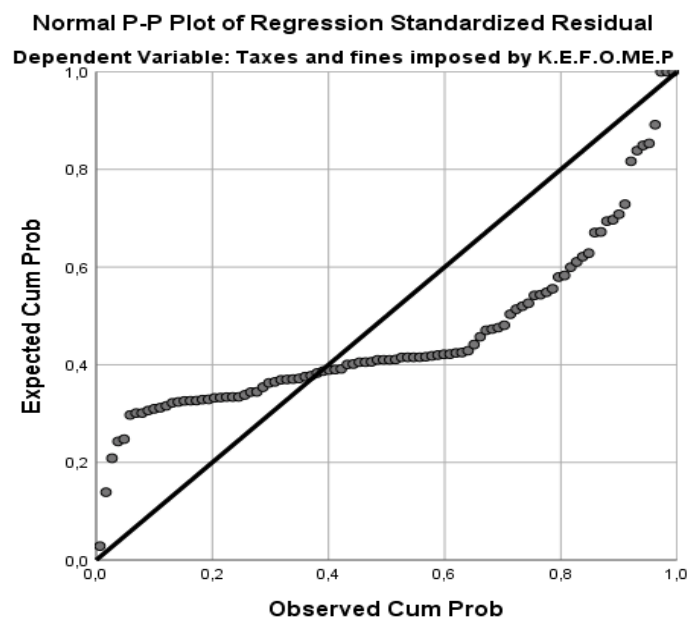

Source: Own study. 
As in the previous model, there are deviations from normality in the case of K.E.F.O.ME.P., but these will not pose a particular problem due to the large sample size.

Table 4. Multilinearity checks - K.E.F.O.ME.P.

\begin{tabular}{|l|c|c|}
\hline & Tolerance & VIF \\
\hline Number of completed K.E.F.O.ME.P. audits &, 991 & 1,009 \\
\hline K.E.F.O.ME.P. staff &, 985 & 1,015 \\
\hline Amounts of money assessed per audit &, 984 & 1,016 \\
\hline
\end{tabular}

Source: Own study.

Table 5. Descriptive regression statistics - K.E.F.O.ME.P.

\begin{tabular}{|l|c|c|c|c|c|}
\hline Model & $\mathbf{R}$ & $\mathbf{R}$ Square & $\begin{array}{c}\text { Adjusted } \\
\text { R Square }\end{array}$ & $\begin{array}{c}\text { Std. Error of the } \\
\text { Estimate }\end{array}$ & Durbin-Watson \\
\hline 1 &, $746^{\text {a }}$ &, 556 &, 541 & 38,07970 & 1,988 \\
\hline $\begin{array}{l}\text { a. Predictors: (Constant), Amounts assessed per K.E.F.O.ME.P. audit, Number of } \\
\text { K.E.F.O.ME.P. audits completed, K.E.F.O.ME.P. staff }\end{array}$ \\
b. Dependent Variable:Taxes and fines imposed by K.E.F.O.ME.P. \\
\hline
\end{tabular}

Source: Own study.

In the two Tables above, we observe that the next two conditions are met since there does not seem to be a problem of multilinearity or autocorrelation according to the results of the relevant audits. The value of the coefficient of determination for the K.E.F.O.ME.P. model is equal to 0.556 , which means that $55.6 \%$ of the variability of the taxes and fines established by K.E.F.O.ME.P. is explained by the amounts of money established per audit, the number of completed audits and the total staff of the service.

Table 6. Coefficients of the regression equation - K.E.F.O.ME.P.

\begin{tabular}{|c|c|c|c|c|c|}
\hline \multirow{3}{*}{ Model } & \multicolumn{3}{|c|}{ Unstandardized Standardized } & \multirow{3}{*}{$\mathbf{t}$} & \multirow{3}{*}{ Sig. } \\
\hline & \multicolumn{2}{|c|}{\begin{tabular}{|l} 
Coefficients \\
\end{tabular}} & \multirow{2}{*}{\begin{tabular}{|c|} 
Coefficients \\
Beta \\
\end{tabular}} & & \\
\hline & B & $\begin{array}{l}\text { Std. } \\
\text { Error }\end{array}$ & & & \\
\hline (Constant) & 43,539 & 22,465 & & 1,938 &, 056 \\
\hline $\begin{array}{l}\text { Number of K.E.F.O.ME.P. audits } \\
\text { completed }\end{array}$ & ,111 & 034 & ,229 & 3,283 & ,001 \\
\hline K.E.F.O.ME.P. staff &,- 155 & ,108 &,- 101 & $-1,439$ & 154 \\
\hline $\begin{array}{l}\text { Amounts of money assessed per } \\
\text { K.E.F.O.ME.P. audit }\end{array}$ & 4,804 & ,460 & ,731 & 10,435 &, 000 \\
\hline
\end{tabular}

Source: Own study.

Table 6 of regression coefficients shows that the coefficients for the number of completed audits and the amounts of money established per audit are statistically significant, since these both have a probability value of less than $5 \%$, which is the level of statistical importance chosen. 
Figure 3. Regression residuals plot-Y.E.D.D.E.

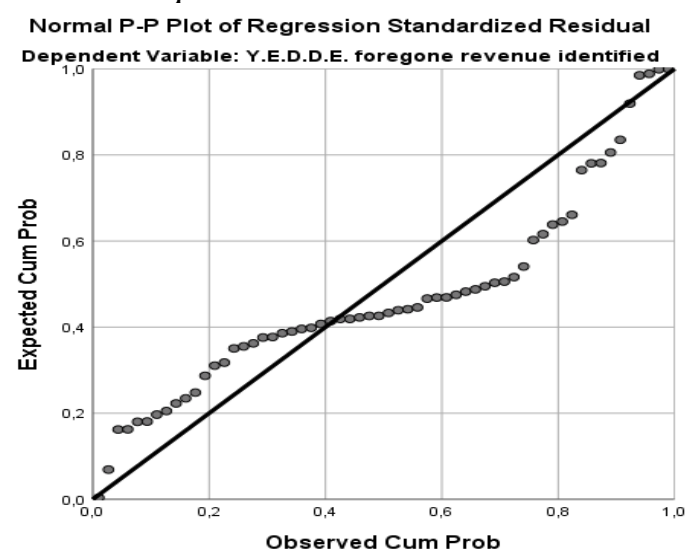

Source: Own study.

Table 7. Multilinearity tests - Y.E.D.D.E.

\section{Collinearity Statistics}

\begin{tabular}{|l|c|c|}
\hline & Tolerance & VIF \\
\hline Number of Y.E.D.D.E. audits completed &, 681 & 1,469 \\
\hline Y.E.D.D.E. staff &, 681 & 1,469 \\
\hline
\end{tabular}

Source: Own study.

Table 8. Descriptive regression statistics - Y.E.D.D.E.

\begin{tabular}{|c|c|c|c|c|c|}
\hline \multicolumn{6}{|c|}{ Model Summary ${ }^{\mathbf{b}}$} \\
\hline Model & $\mathbf{R}$ & R Square & $\begin{array}{l}\text { Adjusted } \\
\text { R Square }\end{array}$ & $\begin{array}{c}\text { Std. Error of the } \\
\text { Estimate }\end{array}$ & Durbin-Watson \\
\hline 1 &, $696^{\mathrm{a}}$ & 484 & 466 & 14221544,01 & 1,664 \\
\hline
\end{tabular}

Source: Own study.

As in the two previous models, it seems that there are relatively large deviations from normality, and there is no issue of multicollinearity, according to the results of the relevant test. The value of the Durbin-Watson statistic is equal to 1.664 , which is less than the threshold of 1.7 that is considered satisfactory, but it is no lower than 1.5 which would be an indication that there is a significant autocorrelation problem in the regression residuals. As a consequence, we may proceed to calculate the regression equation which, as shown in the table above, has a coefficient of determination of 0.484 , which is also relatively high.

Table 9. Regression equation coefficients - Y.E.D.D.E.

\begin{tabular}{|l|c|c|c|c|c|}
\hline \multirow{2}{*}{ Model } & \multicolumn{2}{|c|}{ Unstand. Coeff. } & Stand. Coeffi. & \multirow{2}{*}{ t } & \multirow{2}{*}{ Sig. } \\
\cline { 2 - 5 } & B & Std. Error & Beta & &, 307 \\
\hline$($ Constant $)$ & $-9007548,2$ & 8735295,0 & & $-1,031$ &, 0 \\
\hline
\end{tabular}




\begin{tabular}{|l|c|c|c|c|c|}
\hline $\begin{array}{l}\text { Number of Y.E.D.D.E. } \\
\text { audits completed }\end{array}$ & 301132,2 & 54335,5 &, 639 & 5,542 &, 000 \\
\hline Y.E.D.D.E. staff & 25895,4 & 32407,8 &, 092 &, 799 &, 428 \\
\hline
\end{tabular}

Source: Own study.

Only the variable of the number of completed Y.E.D.D.E. audits turn out to be statistically important, since we see staff has a significance of 0.428 , which is definitely greater than $5 \%$.

\section{Conclusions}

Tax evasion is a grave criminal offence. Concealing income or assets, undeclared work, etc., in order to avoid paying taxes due to the state, is an illegal act and is prosecuted in all countries of the world. The policy for dealing with tax evasion varies from country to country, depending on the economic and political conditions, the tax culture and mentality of each nation but, predominantly, on the extent to which this phenomenon may have grown.

When it comes to Greece, the phenomenon of tax evasion is reinforced by the complexity of the tax system, and the controversy that exists in the law that regulates the relations between taxpayers and tax administration officials. The dysfunction of the tax collection mechanism creates insecurity for both taxpayers and tax administration officials. This is compounded by bureaucracy, technological inefficiencies, and the erroneous tax culture.

In the years of the crisis, these factors were compounded by the continuous increases in tax rates and the simultaneous reduction in the tax-free threshold which, combined with high unemployment rates and poverty, led to a greater number of citizens hiding tax revenues. In Greece, the effort to tackle tax evasion should start with simplifying tax legislation so that it is easier to understand and apply for all taxpayers.

As far as the tax administration is concerned, it should be a modern public institution operating on a system of values such as transparency, fairness, impartiality, meritocracy, integrity, and accountability. The main objective should remain the safeguarding of public revenues through the strengthening of tax compliance and the fight against tax evasion, the implementation of new technical audits, as well as the digitalisation of services related to the fulfilment of tax obligations, while providing high quality services to citizens.

Tackling of tax evasion should be organised on two axes. The first axis concerns the strengthening of voluntary compliance, which can be achieved through preventive actions by the tax administration but, mainly, through the creation of a relationship of mutual trust between the state and the citizens. Taxpayers are disappointed when they see that tax revenues are not used properly or distributed fairly by the 
government. Trust in the state will lead to the cultivation of a different tax mentality and culture which will result in the development of a strong tax awareness which seems to be the only tool to prevent tax evasion.

The second axis concerns addressing non-compliance, which can be achieved by carrying out targeted tax audits on specific categories of taxpayers, as well as carrying out some on-the-spot preventive audits aimed at enhancing tax compliance and combating tax evasion. Systematic controls increase the taxpayer's perception of the likelihood of being audited and therefore reduce the tendency to evade tax.

The empirical analysis revealed that the number of targeted tax audits carried out by the K.E.ME.EP. and K.E.F.O.ME.P. audit centres, as well as the number of partial on-site prevention audits carried out by Y.E.D.D.E., are statistically significant variables for the amounts of taxes and fines assessed and for the detection of revenue leakage.

Therefore, we conclude that the number of audits carried out greatly enhances the fight against tax evasion and, therefore, these control centres, as well as all relevant departments, should be decisively strengthened in order to fight tax evasion as much and as directly as possible. According to all the estimates of the level of tax evasion, reducing it, even by a small percentage, can generate billions of euros in revenue which the Greek economy is in immediate need of.

\section{References:}

Albulescu, C.T., Tămăşilă, M., Tăucean, I.M. 2016. Entrepreneurship, Tax Evasion and Corruption in Europe. Procedia - Social and Behavioral Sciences, 221, 246-253.

Allingham, M., Sandmo, A. 1972. Income tax evasion: a theoretical analysis. Journal of Public Economics, 1(3-4), 323-338.

Alm, J., Torgler, B. 2006. Culture Differences and Tax Morale in the United States and Europe. Journal of Economic Psychology, 27, 224-246.

Annuar, H., Aramide, S., Obid, S. 2014. Corporate ownership, governance and tax avoidance: An interactive effect. Procedia: Social and Behavior Sciences, 150-160.

Artavanis, N., Morse, A., Tsoutsoura, M. 2015. Tax Evasion Across Industries: Soft Credit Evidence from Greece. NBER Working Paper No. w21552. Available at SSRN: https://ssrn.com/abstract=2660011.

Balafoutas, L, Beck, A., Keschbamer, R., Sutter, M. 2015. The hidden costs of tax evasion: Collaborative tax evasion in markets for expert services. The Journal of Public Economics, 14-25.

Blackburn, K., Niloy, B., Salvatore, C. 2012. Tax evasion, the underground economy and financial development. Journal of Economic Behavior \& Organization, 83(2), 243253.

Balios, D., Tantos, S., Eriotis, N. \& Vasiliou, D., 2020. The conjunction of tax auditing mechanism with behavioral and institutional parameters of tax evasion. The role of accounting rules and forensic accounting. European Journal of Accounting, Auditing and Finance Research, 8(2), 59-80.

Bose, N., Capasso, S., Wurm, M.A. 2012. The impact of banking development of the six of 
shadow economy. Journal of Economic Studies, 39(6), 620-638.

Buehn, A., Schneider, F. 2012. Shadow Economies Around the World: Novel Insights, Accepted Knowledge, and New Estimates. International Tax and Public Finance, 19, 139-171. DOI:10.1007/s10797-011-9187-7.

Chen, K., Chu, C. 2005. Internal control vs. external manipulation: a model of corporate income tax evasion. RAND Journal of Economics, 36, 151-164.

Crocker, K.J., Slemrod, J. 2004. Corporate tax evasion with agency costs. Journal of Public Economics, 89(9-10), 1593-1610. https://doi.org/10.1016/j.jpubeco.2004.08.003.

Desai, M., Dyck, A., Zingales, L. 2007. Theft and taxes. Journal of Financial Economics, 84(3), 591-623.

Field, A. 2009. Discovering Statistics Using SPSS, 3rd Edition. Sage Publications Ltd., London.

Frank, M., Lynch, L., Rego, S. 2009. Tax Reporting Aggressiveness and its Relation to Aggressive Financial Reporting, Accounting Review, 84(2).

Goerke, L. 2016. Tax Evasion in a Cournot Oligopoly with Endogenous Entry. http://dx.doi.org/10.2139/ssrn.2905654.

Gokalp, O., Lee, S.H., Peng, M.W. 2017. Competition and corporate tax evasion: An institution-based view. Journal of World Business, 52, 258-269.

Hanlon, M., Slemrod, J. 2009. What does tax aggressiveness signal? Evidence from stock price reactions to news about tax shelter involvement. Journal of Public Economics, 93, 126-141.

Hurst, E., Li, G., Pugsley, B. 2014. Are household surveys like tax forms? Evidence from income underreporting of the self-employed. Review of economics and statistics, 96(1), 19- 33.

Kleven, H.J., Kreiner, C.T., Saez, E. 2009. The Optimal Income Taxation of Couples. Econometrica, 77, 537-560. https://doi.org/10.3982/ECTA7343.

Kaplanoglou, G., Rapanos, V.T. 2011. The Greek fiscal crisis and the role of fiscal governance. The Hellenic Observatory, Papers on Greece and Southeast Europe, GreeSE Paper No. 48.

Mara, P.E. 2015. Emerging Markets Queries in Finance and Business - Determinants of tax heavens. Procedia Economics and Finance, 32, 1638-1646.

Mittone, L. 2006. Dynamic behavior in tax evasion: an experimental approach. The Journal of Social Economics, 35(5), 813-835.

Modugu, K.P., Anyaduba, J.O. 2014. Impact of Tax Audit on Tax Compliance in Nigeria. International Journal of Business and Social Science, 5(9), 207-215.

Mylonas, P., Magginas, N., Pateli, E. 2010. What are the margins for increasing PIT revenue in the Greek economy? Greece: Monthly Macroeconomic Outlook, Strategy and Economic Development.

Palil, M.R., Mustapha, A.F. 2011. Determinants of tax compliance in Asia: A case of Malaysia. European Journal of Social Sciences, 24(1), 7-32.

Phillips, J., Pincus, M., Rego, S. 2003. Earnings management: New evidence based on deferred tax expense. The Accounting Review, 78(2), 491-521.

Radulesku, A.S. 2017. Tax Havens within Legal Boundaries. Older and Newer Cases. The Romanian Economic Journal, 64, 97-108.

Rego, S., Wilson, R. 2012. Equity Risk Incentives and Corporate Tax Aggressiveness. Journal of Accounting Research, 50(3).

Remeikiene, R., Ligita, G., Jekaterina, K. 2014. Country-level determinants of the shadow economy during 2005-2013: the case of Greece. Mediterranean Journal of Social Sciences, 5(13), 454. 
Robinson, J., Sikes, S., Weaver, C. 2010. Performance Measurement of Corporate Tax Departments. The Accounting Review, 85(3), 1035-1064.

Schulz, M., Kalnina-Lukasevica, Z. 2015. Regulation of the European Parliament and of the Council concerning type-approval requirements for the deployment of the eCall invehicle system based on the 112 service and amending directive 2007/46/EC. Official Journal of the European Union, L123, 77-89.

Schneider, F., Buehn, A. 2012. Shadow Economies in Highly Developed OECD Countries: What Are the Driving Forces? IZA, Discussion Paper No. 6891

Slemrod, J., Weber, C. 2012. Evidence of the invisible: toward a credibility revolution in the empirical analysis of tax evasion and the informal economy. International Tax and Public Finance, 19(1), 25-53.

Vlachos, V., Bitzenis, A. 2016. Tax compliance of small enterprises in Greece. International Journal of Entrepreneurship and Small Business, 28, 380.

DOI:10.1504/IJESB.2016.076646.

Vousinas, G.L. 2017. Shadow economy and tax evasion. The Achilles heel of Greek economy. Determinants, effects and policy proposals. Journal of Money Laundering Control, 20(4), 386-404. https://doi.org/10.1108/JMLC-11-2016-0047.

Williams, C., Horodnic, I. 2015. Rethinking the marginalization thesis: an evaluation of the socio-spatial variations in undeclared work in the European Union. Employee Relations, 37 (1), 48-65.

Williams, C., Renooy, P. 2013. Tackling Undeclared Work in 27 European Union Member States and Norway: Approaches and Measures Since 2008. Eurofound. Available at SSRN: https://ssrn.com/abstract=2286337.

\section{ANNEX A:}

Table A1. Variables for empirical analysis

\begin{tabular}{|c|c|c|}
\hline VARIABLE & DESCRIPTION & SOURCE \\
\hline $\begin{array}{l}\text { Total amount of } \\
\text { K.E.ME.EP. audits }\end{array}$ & $\begin{array}{l}\text { Total number of completed inspections (full and } \\
\text { temporary) carried out by the K.E.ME.EP. }\end{array}$ & $\begin{array}{l}\text { https://www.aade.g } \\
\text { r/open-data/KPIs }\end{array}$ \\
\hline $\begin{array}{l}\text { Total taxes and } \\
\text { fines assessed by } \\
\text { K.E.ME.EP. }\end{array}$ & $\begin{array}{l}\text { Total taxes and fines established from completed audits } \\
\text { (full and provisional), in millions of euros, by } \\
\text { K.E.ME.EP. }\end{array}$ & $\begin{array}{l}\text { https://www.aade.g } \\
\text { r/open-data/KPIs }\end{array}$ \\
\hline $\begin{array}{l}\text { Amounts of money } \\
\text { assessed per } \\
\text { K.E.ME.EP. audit }\end{array}$ & $\begin{array}{l}\text { This is the ratio of the total number of confirmed taxes } \\
\text { and fines from completed audits carried out by } \\
\text { K.E.ME.EP. to the total number of completed audits } \\
\text { carried out by the same agency. It is an indicator that } \\
\text { can provide us with an assessment of the effectiveness } \\
\text { of the audits carried out with more specific targeting } \\
\text { and with a greater possibility of detecting and charging } \\
\text { existing infringements. }\end{array}$ & $\begin{array}{l}\text { https://www.aade.g } \\
\text { r/open-data/KPIs }\end{array}$ \\
\hline $\begin{array}{l}\text { Total K.E.ME.EP. } \\
\text { staff }\end{array}$ & Total number of officials serving in this service & $\begin{array}{l}\text { https://www.aade.g } \\
\text { r/open-data/KPIs }\end{array}$ \\
\hline $\begin{array}{l}\text { Total amount of } \\
\text { K.E.ME.EP. audits }\end{array}$ & $\begin{array}{l}\text { Total number of completed audits carried out on } \\
\text { freelancers, high net worth individuals, offshore } \\
\text { companies, and remittances. }\end{array}$ & $\begin{array}{l}\text { https://www.aade.g } \\
\text { r/open-data/KPIs }\end{array}$ \\
\hline $\begin{array}{l}\text { Total of taxes and } \\
\text { fines established } \\
\text { by K.E.F.O.ME.P. }\end{array}$ & $\begin{array}{l}\text { Total taxes and fines established through completed } \\
\text { audits, in millions of euros, established by } \\
\text { K.E.F.O.ME.P. }\end{array}$ & $\begin{array}{l}\text { https://www.aade.g } \\
\text { r/open-data/KPIs }\end{array}$ \\
\hline
\end{tabular}




\begin{tabular}{|c|c|c|}
\hline $\begin{array}{l}\text { Amounts of money } \\
\text { assessed per } \\
\text { K.E.F.O.ME.P. } \\
\text { audit }\end{array}$ & $\begin{array}{l}\text { This is the ratio of the total taxes and fines established } \\
\text { from completed audits carried out by K.E.F.O.ME.P. to } \\
\text { the total number of completed audits of the same } \\
\text { department. It is an indicator that can give us an } \\
\text { assessment of the effectiveness of the audits carried out } \\
\text { with better targeting as well as a greater possibility of } \\
\text { detecting and charging existing infringements. }\end{array}$ & $\begin{array}{l}\text { https://www.aade.g } \\
\text { r/open-data/KPIs }\end{array}$ \\
\hline $\begin{array}{l}\text { Total } \\
\text { K.E.F.O.ME.P. } \\
\text { audit staff }\end{array}$ & Total number of officials serving in this service & $\begin{array}{l}\text { https://www.aade.g } \\
\text { r/open-data/KPIs }\end{array}$ \\
\hline $\begin{array}{l}\text { Leakage of } \\
\text { revenue identified } \\
\text { by Y.E.D.D.E. } \\
\text { investigations }\end{array}$ & $\begin{array}{l}\text { Leakage of revenue identified through VAT fraud } \\
\text { investigations }+ \text { other investigations }+ \text { investigations } \\
\text { following prosecution orders }\end{array}$ & $\begin{array}{l}\text { https://www.aade.g } \\
\text { r/open-data/KPIs }\end{array}$ \\
\hline $\begin{array}{c}\text { Number of } \\
\text { Y.E.D.D.E. } \\
\text { investigations }\end{array}$ & $\begin{array}{c}\text { Completed VAT fraud investigations + other } \\
\text { investigations + investigations following prosecution } \\
\text { orders }\end{array}$ & $\begin{array}{l}\text { https://www.aade.g } \\
\text { r/open-data/KPIs }\end{array}$ \\
\hline
\end{tabular}

Source: Own study. 